\title{
MANAGEMENT OF ENERGY RESOURCES
}

\author{
Prof. dr Slobodan Stefanovic ${ }^{1}$, dr Vladan Vucic ${ }^{2}$, dr Dragoslav Ilic ${ }^{3}$, Prof. dr Radoje Cvejic ${ }^{4}$ \\ ${ }^{1}$ Higher School of Applied Professional Studies, Vranje, Serbia. slobodanstef@gmail.com \\ ${ }^{2}$ YUMIS L.T.D. Nis, Serbia.vladan.vucuc@gmail.com \\ ${ }^{3}$ Public Utility Company "Water" Zajecar, Serbia.dragoslav.dragi@gmail.com \\ ${ }^{4}$ Associate Professor, Faculty of strategic and operational management, Belgrade, Serbia. \\ drradojecvejic@gmail.com
}

\begin{abstract}
Energy is the ability to perform work. This general definition is part of the basic definition of modern physics, in the part that should answer the question about the cause and origin of natural action phenomena, action and power. However, in the ecological point energy is distributed according to her sources, including: conventional and non-conventional sources and in order to provide sufficient power to man for its proper life. It should be noted that the problem of providing sufficient energy to the people on the planet is a huge problem which is pushing humanity. From the producer and the product is required energy efficiency and less energy consumption per unit of product.
\end{abstract}

Keywords: energy, resource, resources, energy management.

\section{INTRODUCTION - Energy resources}

Production of any goods or services requires more or less involvement of different forms of energy. ${ }^{1}$ Energy is constant in nature, andit is in constant motion, which with it is converted from one form to another. From the perspective of eco-management it is most important to emphasize two main forms of energy that can be used for human needs, such as:

\footnotetext{
${ }^{1}$ Energy is the ability of performing work. This general definition is part of the basic definition of modern physics, in the part that should answer the question about the cause and origin of natural phenomena, action, action and power. Every physical system has a certain amount of energy. The amount of energy the system is not an absolute value, but relative to the reference state or reference state. The energy of the physical system is defined as the amount of mechanical work which the system can produce when changing their current situation and took the reference state, for example if a liter of water cooled to $0{ }^{\circ} \mathrm{C}$ or when the car hits a tree and slows down from $120 \mathrm{~km} / \mathrm{h}$ to $0 \mathrm{~km} / \mathrm{h}$.
}
1. Conventional (usual) sources of energy, and

2. Non-conventional (alternative) energy sources.

\section{CONVENTIONAL ENERGY SOURCES}

\begin{abstract}
Conventional (usual) sources of energy, include the use of energy from conventional resources, for which there developed technology solutions. Most of the world's energy needs satisfiesfrom these sources. From an ecological point of view, use of energy from these sources has its advantages and disadvantages.
\end{abstract}

- water energy is obtained by running bodies of water (rivers), and is based on converting water into electricity (hydro). The use of water power is acceptable from an environmental point of view, because the technological process of hydropower has no harmful effects on the environment. The only drawback of the application of water power is that it is in the construction of reservoirs for the smooth operation of hydroelectric power plants must sink (and thus 
irreversibly lose) surrounding landscapes. In addition, the use of water power is limited to areas where there is enough water (river). The transfer of energy produced in this way for long distances (where there is no river) is expensive and not cost effective.

- energy of oil is based on deriving energy from oil that gets its combustion in power plants. The result is a heat that develops during combustion into electricity, which it is distributed to the consumer. Technology of obtaining oil has a number of negative consequences for the environment, the most important being: an imbalance of land from which oil is extracted, the destruction of entire regions by opening the open pit mines, heavy equipment operation, transportation of oil by truck or rail as a special issue stands out tailings (mining waste). There are regulations on safe disposal of tailings and protect the area, but in most cases they are not respected. From the point of view of ecology, energy production in this way is certainly harmful. There are examples of developed countries for these reasons, closed their mines and used (bought and imported) energy from other sources. The problem is the other limited resources like oil, and its non-renewability. It takes thousands of years to the natural processes of fossilization recreate oil that modern humanity consumes in just one year.

- energy from fossil fuels is currently the primary method of obtaining energy for industry and transportation. The whole process of production and use of energy is the origin of this is harmful and environmentally unacceptable. Depletion of fossil fuel sources (oil) requires complex treatment which carries a number of environmental problems. Transportation of oil is also environmentally harmful and fraught with everyday incidents occurring oil spills from tankers or tankers that are happening around the world and leave serious consequences. Refining of petrol and its derivatives is a special pollutant, particularly air, because the air during the broadcast especially dangerous sulfur compounds. Finally, the consumption of gasoline and jet fuel for transportation worldwide is a major source of air pollution and thus the entire planet today.

- wood energy, is acceptable way of generating energy because the wood is considered asa renewable resource. Besides, the burning of wood produce products that are much less harmful to the environment. The use of wood as an energy source is limited to areas where wood is enough, but the way that should still be avoided, because the tree has the most valuable in the forest.

- nuclear energy as an energy source around which now lead separate controversy scientists, technologists, politicians and citizens. Viewed from a purely environmental point of view, energy generation from nuclear power is very environmentally friendly because no harmful emissions and waste generated is extremely small. On the 
other hand, if there is an error in the technological process causes the greatest environmental disasters. In addition, the waste generated is extremely small quantities, but require use of a set of measures for its proper disposal. Burying the closed mine shafts, sinking to great depths or new ideas about launching nuclear waste into space are just some of the ways of trying to solve this problem. The problem of the justification of nuclear power remains an issue to address in the future.

\section{UNCONVENTIONAL ENERGY SOURCES}

The most significant group of these sources of energy are the following:

- solar energy is an alternative source of energy which is the longest and most intensively studied, due to the fact that solar energy is practically unlimited sufficient for the needs of humanity. Energy is obtained by converting solar energy via solar panels into another form of energy (electrical and thermal). The use of solar energy has its advantages and disadvantages. The main advantage of this method of obtaining energy is completely environmental friendly and infinitude of basic resources in the future. The main disadvantage is the cost of equipment needed for this process, which is unacceptable for most households, although investment in the installation of equipment paid through energy savings in five to six years. As of today there are many households that own energy needs to some extent meet this way. Solar collectors have found their application and in specific areas of work, and are often irreplaceable source of energy needed for the climate measuring stations around the world, and isolated houses and cottages, which are often sporadically away from conventional energy sources. In the future we expect the efforts of experts that will lead to a cheapening of the equipment and the reaction of the public to be educated about it.

- wind energy, used since ancient times. The famous windmills have been around for centuries, and some of them work smoothly. Over time, wind turbines was abandoned and people have switched to the production of energy in an easier way. Today, windmills coming back into use, stylish and functionally furnished for the purpose of obtaining energy.

- biomass energy is used sporadically and in our continuously for decades. Most of them were on farms where activities occur as a by-product large quantities of biomass, which otherwise is a waste. Simple process of combustion is obtained mostly thermal energy used for heating of premises. The process is extremely cost effective compared to other things, and therefore many times both economically and environmentally justified.

- tidal energy, there is currently still a very good idea. The attempted implementation of an energy source in this way in France has shown to be effective but also very expensive, 
and therefore can't expect its recent commercialization and wider application. The application of this method of obtaining energy could be extremely valuable, as they ebb and flow of natural phenomena in moving water and therefore not a limited resource.

- geo-thermal energy is used more than the above alternative means of generating energy but not to the extent that it is reasonably possible. Our land abounds in hot springs and hot water is rarely used for energy.

It should be noted that the problem of providing sufficient energy to the people on the planet is a huge problem in pushing humanity since the mid-seventies and the problem of gaining weight. The producer and the product is required energy efficiency and less energy consumption per unit of product.

Therefore everyone thinking about improvements in this respect is useful, but it should be known that the energy savings of only $5 \%$ is extremely environmentally friendly and economically desirable, because it reduces the cost to do so. A kind of "burden" at the quantity of energy consumed in its production parameter whereby developed countries in the near future, determine its value.

From the perspective of ecology and environmental purest form of the applied energy is certainly electricity, but the ways of getting its diverse and often associated with extremely severe environmental consequences.

\section{ENERGY MANAGEMENT}

The term energy management (energy management) is in use because none of our expression (energy management, energy conservation, etc.) is not quite adequate to span the observed matter. Energy management has emerged as a response to the increasing share of energy costs in business and on the other hand, as an attempt to do something about the perceived limited energy resources. Adequate management of power as an end result, the energy savings achieved in the company and the state as a whole, which means that the business is energy efficient, and the state is forced to find its own territory (or imports) of new energy. In this sense, every state should appropriate measures encourages enterprises to rationally manage energy (tax exemptions, employee education, soft loans for the establishment of energy-efficient production, etc.). The initial conditions to be met by a company that wants to reduce costs and optimize energy use are as follows ${ }^{2}$ :

1. Awareness of the need to cut costs, one of the basic requirements of market-oriented enterprises. Energy costs are an integral part of total production costs. In some industries the energy costs are extremely high and a large proportion of burdened cost of the final product. The savings in these enterprises are particularly important, no matter how minimal.

2. Workers are required to implement any business enterprise. As for the rationalization of energy consumption is necessary to all employees appropriately educated to accept the importance of saving energy wherever possible. It is believed that each employee may go some way to contribute to the reduction of energy consumption, regardless of the position in which it is located, or the type of work they

\footnotetext{
${ }^{2}$ Miljkovic, R, Kukoleca, P., Filipovic, J., Gavrilovski,M,: Strategy for the Energy Efficiency Improvement in the Iron and Steel Industry Corporation Sartid Yugoslavia, International Metalurgy and Matterial Congress, Istanbul, Turkey, 1997.
} 
perform. Energy savings realized by the employees themselves, without specific technological change, can go up to as much as $20 \%$ of the total consumption, which is more than satisfactory result was achieved without additional investments.

3. The organization is one of the important factors for successful implementation of the optimization of energy consumption. In this regard, it is necessary to examine the effectiveness of existing organizational chart of companies and if necessary to make certain changes in the organizational structure. In this segment, too often does not require any significant financial investment.

Correctly applied the above conditions is a precondition for the optimization of energy costs and the company can expect the economic effects of the changes implemented in the very near future. Basic menagement measures energy can be planned and implemented in the following time frames:

1. Short-term measures, mainly related to the elimination of unnecessary energy waste and hospitable attitude towards energy. These measures do not require any specific investment, but usually adequate education and referral of employees in need of saving. Effects of short-term measures to return soon, but after one or two years.

2. Medium-term measures related to significant modifications in the manufacturing process and require greater investment. This primarily refers to the replacement of worn parts and machines that often consume more energy than required, installation of new equipment to accurately measure and control spending, etc. Investments in these changes are a little larger, and returning to an average of five years.

3. Long-term measures include significant investments in the introduction of energy efficient technologies, planning and implementation of energy from alternative energy sources, reconstruction of production facilities, using of insulation material, absolutely prevent energy waste and the like. These measures require adequate planning, more financial resources and time to implement, so that their positive effects can be expected after more than five years.

\section{IMPLEMENTATION PHASE OF ENERGY MANAGEMENT PROGRAM}

These stages are as follows ${ }^{3}$ :

1. Control of the earlier use of energy; as phase which involves gradually the country's overall energy cycle of the company, including the following:

- Identification of sources of energy used (origin and quantity, both total and by individual manufacturing and non-manufacturing areas). In this way, an insight into the amount of energy (electricity, gas, petrol)

\footnotetext{
${ }^{3}{ }_{3}$ Martocci, A., P.: Enenrgy: Consumption, Cost and Conservation in the Steel Industry, iron and steel Engineer, USA, 1996.
} 
that are consumed during the month or year,

- determine ways and efficiency of the internal energy transfer in the company from entry to the place of consumption, which simultaneously receive data on the possible energy losses during transmission, which is determined separately for each type of energy used,

- determination of the consumption of all forms of energy in particular. Given that energy is used in virtually all areas of the company, it is to be fixed at the place where consumption is highest,

- consideration of the problem of socalled. waste energy, which is energy that can be obtained using the waste nuzprodukata production.

2. The establishment of norms and standards, is the stage that follows, and includes a rational and critical analysis of previously acquired facts and to establish the norms of energy consumption which are considered acceptable to a certain place and a certain type of energy. Very often consumes more energy than is objectively necessary. Standardization of energy consumption should be explained and all workers should be aware of this.

3. Determining the real cost of energy, depending on the production process if it is possible to implement the objective of the previous phase. Then it is possible to get a true picture of how many of which types of energy consumed in production.

4. Quantifying the measure of energy management, is the stage at which it clearly states on the basis of the previous parameters, which are the places and ways in which power consumption can be reduced without affecting the efficiency of operations. Management of the company at this point selection means that intends to invest in the rationalization of energy consumption and determine the schedule of implementation of selected short-term, medium-term or long-term plan.

5. Determining the share of energy costs in total costs is the result of changes brought about by saving certain amount of energy, and takes into account the new, altered mental state after adjustments in the production process and the behavior of employees. In this way, insight into the reality of the load operation energy costs, and an insight into the extent of the financial savings that have been realized. Cost reduction implies the possibility of reducing the price of goods (services).

6. Increasing the competition in the market is the ultimate goal of the measures implemented and occurs primarily as a consequence of lower product prices while maintaining quality. On the other hand, the company operates the rational consumption of energy in accordance with the concept of sustainable development, thus creating a positive image in the region, thereby acquiring the additional favor of consumers and the general public.

7. Significant financial savings, the company is left as a result of rationalization of energy consumption. It should be noted that 
the savings can and should be used in further activities aimed at optimizing the energy consumption or other activities to rational utilization of resources.

\section{EFFECTS OF ENERGY MANAGEMENT}

\begin{abstract}
Implementation of adequate management of energy has multiple positive effects on all of society's institutions. The positive effects of energy management that occur in some areas are as follows ${ }^{4}$ :
\end{abstract}

1. The community has direct benefits of successfully implemented energy management for reducing exploitation of energy resources and preserving the quality and quantity of the future. Reducing costs to the positive business from which the state has used in the collection of the tax and other liabilities.

2. Manufacturers of energy, as the first in the power chain also have a kind used while saving energy means reduced consumption. Manufacturers of energy due to reduced spending to reduce the cost of their own businesses, postpone the construction of new generating capacity and avoid the risk of being unable to meet the needs of the consumer, leading to an overload of the energy system, it turns out all of the power systems and planned or unplanned power restrictions.

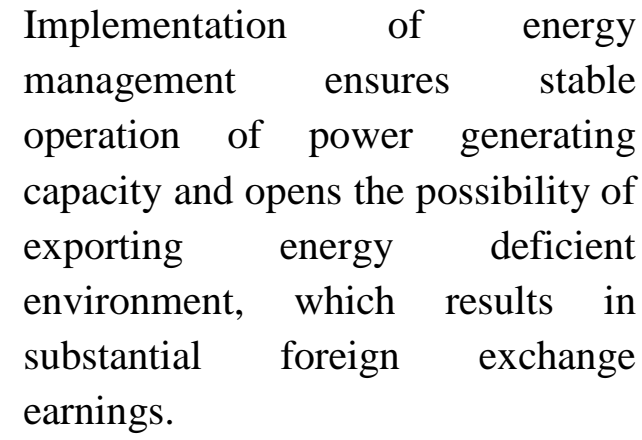

3. Energy distributors can count on reducing the cost of energy transfer, better use of existing capacities and their modernization,

4. Energy consumers (companies) have reduced energy management costs assumed power, reduced cost of energy, security of energy supply, reduced product prices and create a positive image of an environmentally responsible company.

\section{CONCLUSION}

Implementation of the business concept of pollution prevention organization acquires a number of benefits. First of all, reduce the various costs and increasing profits, improving the safety of employees, increased productivity, better protection of the environment, preserves resources and enhances the image of positives.

Cost reduction is a common result of implementing eco-management and observed over a longer period of time. Practice has shown that a number of ecomanagement projects and investments have a short period of return on investment. In addition, costs are reduced energy and water use, disposal costs, and rational use of raw materials. Unfortunately, in practice it is often under-emphasizes the possibility that the business eco-management systems

${ }^{4}$ Ritt, A.: The Benefits of Hot-Charging Slabs, New Steel, USA, 1996. 
can significantly affect the reduction of operating costs.

Improving the safety of employees is achieved by reducing or eliminating the use of toxic materials in the workplace, which can reduce the costs that arise because of the application of health and safety, as well as the renovation costs of occupational injuries.

The increase in productivity due to the fact ofimplementation of pollution prevention programs establish efficient processes and efficient use of raw materials, energy, time and labor. Sometimes very small changes can lead to significant cost savings and improve business productivity.

Improvement of the environment is created as a logical consequence of the efforts of the company to operate an environmentally responsible manner. Rational use of resources, reduce waste and similar commercial priorities have a positive impact on the environment.

Quality improvement is imperative for today and investing in environmental quality aspects are of special interest by consumers and stakeholders. Quality improvement must be continuous.

Resource conservation is a consequence of the application ecomanagement programs that are primarily designed for reduced use of raw materials, energy and water, and consequently, to reduce the generation of waste.

Improving the image of the organization is the final result of implementing eco-management software business. In this way, organizations prove that they are ready to implement certain changes to take account of the requirements of the community when it comes to the quality of the environment. Consumers these changes very positively and environmentally responsible organizations prefer.

\section{REFERENCES}

1. A.Bramnjel(1989), Ekology in the 20 the century a history, Yale University Press, New Hawen an London.

2. Annon., Onsite (1980) Wastewater Treatment and Disposal Svstems. EPA/625/1-80/012. VV'ashington DC 20460.

3. Andre, M.P., iŽ. Mitrović (1996), Osnove modela ekološkog sistema, Beograd, Yupiq, Kultura.

4. Barkley, A. (2002),Organic food growth, Department of Agricultural Economics, Kansas State University, USA.

5. Baumgarten $\mathrm{H}$., Wiendahl $\mathrm{H}$, Zentes J.(2002),’Logistik-Management”, Band 1 i 2, Springer Verlag , Berlin Heidelberg.

6. Draft International Standard ISO/DIS 14041. ISO, Switzerland, 1997.

7. Edwards-Jones, G., and B. Davies, S. Hussain (2000),Ecological Economics anintroduction. London, Blackwell Science.

8. Martocci, A., P. (1996), Enenrgy: Consumption, Cost and Conservation in the Steel Industry, iron and steel Engineer, USA, 1996.

9. Ritt, A. (1996), The Benefits of HotCharging Slabs, New Steel, USA.

10. Roberts, R. (2005),Implementacija sistema ekološkog menadžmenta ISO 14001: 2004, prevod, Mobes quality, Novi Sad.

11. Sawyer, C.N., McCartv, P.L., Parkin, G.F. (1994) Chemistry for Environmental Engineering, McGravvHill, Inc.

12. Stevenson, E. Kenneth., Bernard, T. Dane,(1995),HACCP Establishing Hazard Analysis Critical Control Point Programs. A workshop manual. Second edition. The Food processors Institute. Washington. USA.

13. Tibbs, B., C. (1992),Industrial ecology, An environmental agenda for industry, USA.

14. Tylecot, A., Straten, van Der, J. (1997),Introduction 
Technology and Institutions, Edward Elgar, London.

15. Tyler G. (1981): Heavy metals in soil: Biology and biochemestry, 5: 371-413.

16. Veselinović D., Gržetić I., Đarmati Š., Marković D., (1995), Stanje I procesi u životnoj sredini, Fakultet za fizičku hemiju, Univerziteta u Beogradu, Beograd.

17. Gereke, Z., I V. Filipović (1994),"Ekologija kao generator novih tržišnih zaokreta”. SymOrg’94, III međunarodni simpozijum "Menadžment na pragu XXI veka", Zbornik radova II, Zlatibor, FON.

18. Gereke, Z. (1995), Ekologija I organizacija, Beograd, Znamen.

19. Miljković, R, Kukoleča, P., Filipović, J., Gavrilovski, M, (1997), Strategy for the Energy Efficiency Improvement in the Iron and Steel Industry Corporation Sartid Yugoslavia, International
Metalurgy and Matterial Congress, Istanbul, Turkey.

20. S. Stefanović, LJ. StošićMihajlović, V. Vučić, P. Jevtić (2013), Menadžment u zaštiti životne sredine, TQM Centar, Zrenjanin.

21. Stefanović S., CvejićR. (2010), Ekološki menadžment, TQMCentar, Zrenjanin, 2010.

22. Stefanović S., Šubara N. I dr. (2008), Ekološki rizici - Uticaj negativnih faktora na kvalitet života, Instutut za energetiku I ekologiju „TEHDIS“, Zrenjanin, 2008.

23. Šubara N., Stefanović S., (2008), "Ekološka logistika”, Društvo za tehničku dijagnostiku, Beograd, 2008.

24. Šubara N., Stefanović S., i dr. (2008), "Saobraćajna ekologija", Društvo za energetsku efikasnost

25. Banja Luka, 2008 